\title{
Melting Moments: The Greasy Sources of Modern Perceptions of Fat
}

\author{
Christopher E. Forth, University of Kansas
}

In 1822 a rather bizarre satirical piece turned up in Blackwood's Edinburgh Magazine. Occasioned by the recent challenge that Thomas Malthus had launched against the economic theories of Jean-Baptiste Say, a cheeky yet anonymous writer intervened with a report on a fictitious German economist named 'Professor Gunthred Bumgroschen', ${ }^{1}$ whose theory of 'save-all-ism' represented a unique contribution to the debate. Upon a visit to England, it seems, the good professor had been struck by the size of its inhabitants, who took up more space on the streets than the slender Parisians across the Channel, prompting him to speculate on how the British might make the most economical use of their excess fat. Explaining how Bumgroschen considered the human corpse to be 'a valuable mass of materials' that 'ought not to be suffered to undergo a useless decomposition in a deep grave', this author proposed - with tongue firmly in cheek - that a reformed Britain would take better advantage of its corpulent dead. Bumgroschen's plan was to transform the nation's 'morbid accumulation' of fat - which had been 'a noxious mass to the individual while living' - into 'a valuable accumulation for posterity'. This would be accomplished by melting fat corpses to make soap and oil.

Hygiene, both personal and moral, would be the two main benefits of Professor Bumgroschen's unorthodox plan. Those unfortunates who might have otherwise worn flannel or unlaundered clothes would now be able to don white muslin and clean shirts as a matter of course. So rich were British fat supplies that they would provide enough soap 'to keep the entire world clean', thus extending the virtues of hygiene beyond the island nation. There would even be enough to render the

Cultural History 1.1 (2012): 83-107

DOI: $10.3366 /$ cult.2012.0007

(C) Edinburgh University Press www.eupjournals.com/cult 
Jews and the 'Sisterhood of the Blue Stocking' presentable. Fat not earmarked for soap production would be made into oil that, when volatilized, would power a 'new gas-light company, and the whole metropolis will be flooded with a deluge of light'. Gone would be the dark alleyways and other shady places where fraud and corruption bred, and 'every man will know his own wife at night'. Through the seemingly miraculous processes of rendering and distillation a revolting substance would now serve 'the important purposes of health through the medium of cleanliness, and to the advancement of morality by the diffusion of light'. People who might have been otherwise worried about their weight could now lie back and think of England: 'What a delightful reflection for the corpulent of both sexes, that their fat will eventually come into play! How charming the anticipation of these melting moments! ${ }^{2}$

Readers who chuckled at the absurdity of Bumgroschen's idea would have conceded a grain of truth in his assessment of British corpulence. Long before Americans seized the title the English were considered the fattest people in the Western world, an accomplishment generally attributed to their cold and moist climate as well as the commercial success that encouraged elites to eat more and exercise less. If the portly figure of John Bull conveyed this happy sense of English prosperity, real fat men, like the 700-pound Daniel Lambert, loomed large in the national imagination, even firing the fantasies of foreign tourists who hoped to spy a legendary fat Englishman waddling down the street. ${ }^{3}$ Yet if many bourgeois saw rotundity as proof of financial status, such ample proportions were also subject to criticism on medical, moral, and aesthetic grounds, a critique that grew more acute in the opening years of the nineteenth century. Moreover the same fat that signified prosperity may have also reflected misgivings about consumption as well as the rapid expansion of the Empire after the Napoleonic wars. ${ }^{4}$ During this time fat people were not only the subjects of caricature at the hands of artists like James Gillray and Thomas Rowlandson, but were skewered for their ugliness, stupidity, and sickness in the books and articles that William Wadd wrote about corpulence. ${ }^{5}$

As vexing as the issue had become by 1822, the Blackwood's article did more than comment on corpulence. It reminded readers of fat's role as a lucrative commercial product, and thus of its uses outside of the body. As British soap consumption more than tripled in the first half of the century, and the rapid expansion of industrialization required more lubricants for machine parts, overseas colonies became important sources for the vegetable oils needed to tend machines and bodies. ${ }^{6}$ In one form or other fat literally oiled the machinery of 
industry and empire while washing offending dirt and grease from fabric and skin. Although coal-gas was widely employed to illuminate the streets of London, gas manufactured from oil - particularly whale oil and sperm oil derived from blubber-remained a strong competitor during the early decades of the nineteenth century. ${ }^{7}$ Of course no one was actually using human fat to light city streets, but candles made from the stuff were not unknown, and soap rendered from human adipose could be found if one looked hard enough. ${ }^{8}$ After the Parisians dug up the overcrowded Cemetery of the Innocents - only to find corpses that had turned into a fatty substance called adipocere (or 'cemetery fat') - they supposedly handed them over 'to the extent of many tons' to the 'soap-boilers and tallow-chandlers of Paris, for the manufacture of soap and candles'. ${ }^{9}$ Although several retorted that not even the French would do such a thing, the notion that massive amounts of human fat could be transformed into a source of cleanliness and illumination was certainly in the air. Eventually the idea wafted across the Atlantic, where in 1880 one enterprising author calculated that the 250 people who died each day in New York could supply the city with '190,000 cubic feet of bright illuminating gas' ${ }^{10}$ By the early twentieth century it was even alleged that in Paris 'some of the leading pharmacies stock a high-priced soap, known as human-fat toilet soap, costing 5 francs $(\$ 1)$ per small cake. It is perfectly pure, genuine soap, unscented, yellowishwhite, and the fat is obtained from cadavers in the hospitals - usually from the submerged-tenth unclaimed class. It has been made for over a century to meet a limited demand, and Paris medicos have recommended it as a better emollient than ordinary soaps.' ${ }^{11}$

In addition to reminding people of the troublingly instrumental things one could do with human bodies, such proposals and fantasies entertained the idea that one could convert, as if through an alchemical process, a foul and base substance into something beneficial for the purposes of cleanliness, illumination, and even morality. It is this attention to the ambiguous physicality of fat that may have implications for how we approach the 'disgust' feelings that corpulence often elicits in the West. Scholars disagree exactly when 'obesity' became the problem it is for us today, but many concur that our current anti-fat stereotyping is a particularly 'modern' phenomenon, one that has developed in fits and starts since the 1500 s to become much more pronounced since the 1920s and especially during the closing decades of the twentieth century. ${ }^{12}$ This claim is correct in its broadest sense. One can easily demonstrate that physical ideals for men and women have changed over this long 
expanse of time, and point to new techniques of self-control being practiced by aristocratic members of the 'court society' as well as a growing emphasis on personal appearance as providing social cues about the inner person. So self-evident does the modernity of fat prejudice seem that one scholar even dubs the entire premodern world a 'time before fat', a time before a new bodily aesthetic altered accepted ideas about shape, size, and appearance. ${ }^{13}$

While acknowledging that corpulence was indeed a matter of aesthetics early in the nineteenth century, the Blackwood's article also shows that oil and fat are more or less the same stuff in different states. Bumgroschen thus reminds us that, as an artefact of the cultural imagination, fat also refers to a material substance whose meanings are in no way contained within the boundaries of human skin. In light of our contemporary tendencies to focus on size and shape as the most pressing moral and aesthetic issues that structure fat stereotypes, it is worth considering that fat also has a cultural life outside of its relationship with the human body and its appearance. This is one reason that numerous stereotypes about fat people today make use of senses that go well beyond the visual. Given that the 'disgust' that fat people are said to elicit is also linked to their 'soft', 'flabby', 'greasy' and 'smelly' bodies, we might consider the roles of touch and smell in the formation of fat stereotypes. To understand the social construction of disgust, then, we need to engage with fat as being about something more than size and shape. ${ }^{14}$

This article contends that analyses of the modernity of fat stigmatization in the West - as a largely visual matter that foregrounds size and appearance - must also include a consideration of the materiality of fat as an historically ambiguous substance, the qualities of which have played an important role in structuring perceptions of corpulence since the early modern era. This broad claim is supported by a wide-ranging analysis of how ideas about human fat in Britain and France vacillated over time between an appreciation for its vital intrinsic qualities and its troubled status as a form of greasy 'excrement' that frustrated the hygienic and racial selfperceptions of white elites. This is supplemented by a brief exploration of the colonial aspect of fat intolerance, specifically the powerful links being forged towards the end of the eighteenth century between certain non-Western cultures and an appreciation of grease and corpulence. This largely neglected racial dimension may shed light on some of the strong reactions that fat would come to elicit by the twentieth century. Approaching fat in such ways entails a rapprochement between constructivist theories of the body and 
recent work on materiality emerging from anthropology and archaeology. It concurs with Nicole Boivin that the physicality of the material world is not simply a 'text' to be interpreted, but a reality with properties and dimensions that cannot be completely reduced to social determinants. Indeed 'in many cases, ideas and cultural understandings do not precede, but rather are helped into becoming, by the material world and human engagement with it'. ${ }^{15}$ Material symbols are therefore not completely 'arbitrary' in relation to the concepts they signify, but also refer to 'a physicality which resists and enables'. ${ }^{16}$ Rather than determining culture in any direct way, these material qualities 'remain available, ready to emerge as real factors' in various contexts and at different times, and are often 'bundled' together with a spectrum of other social relevant qualities. ${ }^{17}$ By attending to the materiality of fat this article proposes a more complex historical understanding of the development of stereotypes about corpulence.

\section{The Ambiguity of Human Fat}

In order to understand some of the ambivalence that fat has generated since the sixteenth century we must briefly consider the ancient sources of our modern concerns. We know that fat has long been linked to concepts of fertility, both in terms of the plumpness that is often prized in ripe fruits and vegetables as well as in animals reared for human consumption. It has also been used to describe soil or fields capable of producing considerable yield. Yet if fat is linked to ideas of increase that have also applied to human bodies, it has also denoted greasy and sticky substances with properties that are tactile, olfactory and gustatory as well as visual. Some propose that fats and oils belong to a class of culturally ambiguous substances that includes wax, tallow, tar, and pitch. The link between these different forms of fat has been emphasized since antiquity, when fats and oils were viewed as the very stuff of vitality, strength, and life. ${ }^{18}$ When Aristotle likened the life of the body to a lamp in which the flame slowly consumes its oil, his simile rested on the assumption that the moisture of the body was in fact unctuous: bodily 'heat is fed by moisture, not, however, by any kind of moisture but by that which is smooth and fat'. ${ }^{19}$ The Greeks believed that, when rubbed on the skin, fats could impart some of their power to the body, and when scraped from the skin sweat, oil and dirt were thought to have medicinal properties. ${ }^{20}$ Moreover soil that was called 'fat' (crassus, pinguis) had a distinctive greasy texture and sticky consistency that experienced farmers recognized. ${ }^{21}$ Fertile soil was thus literally fat, not metaphorically so. What held true for fields also 
pertained to bodies: it is widely acknowledged that a certain plumpness of physique has long offered evidence of health and strength in the West and in other parts of the world.

These seemingly 'positive' qualities of fat were balanced by the more unsettling properties of fats and oils. Not only does fat have the capacity to change its state from solid to liquid and back again, but, through the process of combustion, fat that is burned can dematerialize into smoke and light. $^{22}$ Fat may therefore be transformed from a state of 'gross' or 'dull' materiality - which is how it has often been described - into something subtle and even transcendent. If in Roman culture grease sometimes counted as a form of 'filth' capable of eliciting disgust [ fastidium] ${ }^{23}$ the greasiness of soil was also considered potentially problematic: excessively fat fields could be so fertile that they were on the verge of decay, suggesting a limit beyond which the boon of ripeness could mutate into a disturbing rottenness. Many authors writing since antiquity noted how, in both fields and animals, excessive fat resulted in overgrowth, sterility, and decay. In his massive compilation of classical knowledge Pliny the Elder contended that fat plants may suffer from 'obesity [obesitate], for instance all which produce resin owing to excessive fatness [pinguitudine] are converted into torch-wood, and when the roots also have begun to get fat, die like animals from excessive adipose deposit' ${ }^{24}$ Finally, in the moral realm both olive oil and excess body fat could be connected to Greco-Roman anxieties about the softness of 'luxury', a concept with roots in agricultural ideas about overgrowth and decay. In addition to denoting unregulated appetites and superfluity in speech and manner, corpulence was a form of 'softness' that could also call to mind livestock being 'fattened' for the slaughter. ${ }^{25}$ The fatness of Roman elites - including generals and emperors - was thus an ambiguous trait capable of signifying wealth and status as well as luxury and decay. ${ }^{26}$ Rather than an unequivocally 'good' substance, then, in the ancient world fat 'spills over conceptual binary boundaries and functions much like a cultural trickster, connecting with both life and death'. ${ }^{27}$

Drawing as it did upon ancient antecedents updated since the Middle Ages, early modern fat also has a complex history of being related both to fertility and life as well as putrefaction and death. Some of this pertained to human fat, which in one form or another had been part of the European pharmacopeia since ancient times. In the mid sixteenth century Andreas Vesalius instructed anatomists who boiled bones for the study of skeletons to carefully collect the layer of fat 'for the benefit of the masses, who ascribe to it a considerable efficacy in 
obliterating scars and fostering the growth of nerves and tendons' ${ }^{28}$ It was also considered especially effective in healing wounds. Battlefields were an excellent source of human fat. Conquistadors harvested it from the bodies of slain Indians, and, after a particularly bloody battle during the siege of Ostend in 1601, Dutch physicians descended upon the battlefield to return with 'bags full of human fat' to add to their stores. ${ }^{29}$ During peacetime executed criminals provided a more regular supply. Not only was their sweat collected and prescribed for haemorrhoids ${ }^{30}$ but 'poor sinner's fat' rendered from the bodies of the recently killed was used to treat a range of illnesses. Human fat was also in high demand among medical professionals. Through the eighteenth century European executioners prepared and administered homemade remedies from the fat of their less-than-willing suppliers, and enjoyed a lucrative trade in the fat they delivered to physicians by the pound. ${ }^{31}$ Even as the executioners' trade tapered off around the 1750 s the wise druggist continued to keep large supplies of human fat on hand alongside numerous other solids and liquids derived from human corpses, a class of materia medica known as 'mummy'. ${ }^{32}$ And if fortune smiled on the fat trade when the rate of executions increased, it was positively beaming during the Terror days of the French Revolution. Certain Parisian butchers supposedly sold graisse de guillotine procured from the corpses of the freshly executed. ${ }^{33}$

What was it about human fat that made it so sought after? And what was so special about the fat of criminals in particular? In some respects the practice echoes the Catholic cult of holy relics, whereby the sacredness of saints was considered to be fully present in their bodies after death, as well as in the objects they touched. Yet this mystical appreciation only explains so much, and, needless to say, many executed criminals were no saints. In fact the medical use of fat was perceived as being a natural rather than magical practice, and thus based on ancient assumptions about the inherent vital properties of the substances themselves. There was thus no clear distinction between the material and the symbolic in these healing practices, even if much of it seemed magical from the patient's perspective. ${ }^{34}$ Despite the apparent obsolescence of many of these beliefs, the claim that fat could heal wounds was not entirely misguided: physicians today know that adipose tissue is highly 'angiogenic', meaning that it promotes the growth of new blood vessels from pre-existing ones. Fat could have been used in this way simply because it seemed to work. ${ }^{35}$ The reasons people gave for why it worked seem less persuasive today. Many believed that the vital force of the human being lingered in the body after death. This vitality, they contended, was strongest in the bodies of 
healthy young men who had died violently, especially - as in the case of an execution - when death came so swiftly that the life force had no time to evacuate the body. ${ }^{36}$ This is why the fat of those who died young and violently was especially prized.

This widely acknowledged trafficking in human fat gave rise to fears of the illicit harvesting of the precious substance, some of which dovetailed with wider anxieties about 'cannibalism' and the supernatural. In a tradition extending back into the Middle Ages, especially in Germanic cultures, thieves sometimes believed that their nocturnal pilfering would go unnoticed if they burned a candle made of human fat. As long as these 'thieves' candles' burned, it was believed, burglars would attain the powers of invisibility while homeowners remained blissfully asleep. So powerful was this belief that in the sixteenth and seventeenth centuries several thieves were executed for murdering people just to make such candles ${ }^{37}$ - and no doubt had their own fat cut from their corpses for use in medicines and other concoctions. In addition to expressing discomfort at the thought of having their bodies dissected and parcelled out to doctors and patients, condemned men were worried that their fat would be used to make the unguents that supposedly gave witches the power of flight and facilitated the transformation of humans into werewolves. ${ }^{38}$ Witches were a particular concern in the sixteenth century, not least because they were said to steal the fat of Christian infants to make their unholy grease. Yet allegations of unauthorised fat extraction cropped up in other contexts, often employing ancient ingestion motifs as a means of demonstrating how one group literally or figuratively 'devoured' another. When French Protestants were killed on St Bartholomew's Day in 1572 it was rumoured that their fat had been extracted and sold at public auction. ${ }^{39}$ Similar allegations cropped up throughout the early modern era. In 1747 a great fear gripped the Alpine community of Primarette, where stories circulated that lords and clerics connected with the local glassworks had sent werewolves to procure the fat and flesh of children for use in glassmaking. ${ }^{40}$ More fat was allegedly taken during the French Revolution. In the troubled Vendée region soldiers loyal to the revolution supposedly created a makeshift rendering facility to extract the fat of one hundred and fifty women, casks of which were sold to citizens who found it 'a thousand times more pleasing than lard'. ${ }^{41}$

The fact that druggists kept supplies of human fat and other body parts on hand does not mean the practice had the seal of approval of doctors, many of whom had long argued that there was nothing special about human (as opposed to any other) fat. In fact by the 
mid-eighteenth century professional medical interest in human fat had clearly waned. 'At present', one physician reported, 'we are grown wise enough to know, that the Virtues ascribed to the Parts of the human Body are all either imaginary, or such as may be found in other animal Substances'. ${ }^{42}$ Such disapproval was compounded by a growing competition between doctors and executioners for access to dead bodies, the result being that the procuring of corpses was eventually taken out of the hands of executioners altogether.

Of course this did not diminish the clandestine traffic in fat harvested from humans. In fact a thriving fat trade had been operating for years out of the dissecting theatres of Paris, but its eventual discovery in the early nineteenth century was kept quiet for fear of alarming the public. Before being caught red-handed by the police agents who had been tipped off to their activities, medical assistants connected to various dissecting rooms had joined forces with their counterparts at the Faculty of Medicine to bring the fat to the people. The medical assistants were hardly discrete about their actions, which seem to have been well known to everyone except the faculty administrators. Police raids revealed that at least four of the entrepreneurs had been storing the stuff at home - one was caught with a whopping two thousand litres of it in his apartment and another, presumably lacking more suitable containers, had filled two sandstone fountains with purloined fat. While reminiscent of older practices the Paris fat trade reflected an important shift in focus. While a fair amount was sold to medical charlatans (or used to grease the wheels of medical carts), it was the city's enamellists and fake pearl makers who benefited most from this trade, thinking they were receiving fat procured from horses or dogs. ${ }^{43}$

This more 'industrial' use of human fat comes closer to the materialist perspective of Professor Bumgroschen, who was less concerned about the vital properties of the substance than its potential uses for cleaning bodies and lighting streets. In that sense his proposals came at an important crossroads in European perceptions of human fat. While the vital properties that seemed inherent in fat - and which fostered anxieties about real and imagined beings who threatened to steal this substance from the body-persisted in the popular imagination throughout the eighteenth and nineteenth centuries, such qualities were also being systematically demystified through a number of developments that not only effectively rendered fat 'dead' but also connected it to processes of immorality, filth, and putrefaction. Some of these changes were medical and scientific, leading to new discoveries about the chemical 
composition of fats - as well as more overtly mechanistic views of the body and nutrition - that would further develop in the nineteenth century. ${ }^{44}$ Other developments were closely linked to shifts in morality and social class that reflected shifts in the sensoria of white elites. As the next section of this essay shows, the vital qualities that made fat so coveted as a medical ingredient during this period were in a state of tension with its manifestation as sweat and grease.

\section{Between Grease and Grace}

As noted above, grease has been an ambiguous substance since antiquity; yet the unfavourable connotations of 'greasiness' seem to have mounted around the mid-1500s, notably in northern Europe where religious reformers condemned the use of holy oil in Catholic rites. ${ }^{45}$ Even among Catholics grease and fat signified sensuality and materialism, and were commonly cited in religious texts as a material symbol of high living as well as moral and corporeal corruption. ${ }^{46}$ In France the carnality of grease and fat even extended to popular speech, where those who uttered obscenities were said to 'talk fat' (parler Gras) or to have a 'fat tongue' (la langue Grasse) ${ }^{47}$ For centuries the greasy drippings and other effluvia collected from the kitchens of elites were peddled on the streets of European cities, destined either for soap makers, tallow chandlers or, more likely, the tables of the poor. This foul 'kitchen stuff' was colloquially linked to the figure of the plump kitchen wench or any female domestic servant whose 'greasy' sexuality aroused illicit desire as well as moralizing alarm. ${ }^{48}$ The character Nell in Shakespeare's A Comedy of Errors is an excellent case of the 'fat' kitchen wench whose 'greasy' sexuality was intimately related to her shape and even texture. This 'very beastly creature' promised to make a 'fat marriage' because she herself was 'all grease', from her tallow-drenched clothes and grimy face to a body that was spherical 'like a globe; I could find out countries in her'. ${ }^{49}$ It is perhaps no wonder that in England the dubious-sounding remedy known as 'oil of man', the recipe for which called for the melted fat of criminals, was also a slang expression for semen, 'an oyle which women should not (unlawfully) tast of ${ }^{50}$ Oils and anointments also had uses linked to sexuality: when infused with certain herbs they had heating properties that elicited desire and heightened pleasure, and when applied to the vagina or anus their lubricating properties could facilitate intercourse. ${ }^{51}$

Oil and grease thus appear as slippery substances, materially as well as conceptually, capable of sliding between positive and negative connotations depending upon context. Grease and sweat were 
especially problematic in the world of manners. Among elites wiping the grease from one's fingers with a napkin or cloth (rather than licking them clean) was considered a habit worth instilling in boys as part of their overall education in civility. ${ }^{52}$ Nobles also registered growing discomfort about sweat, a form of 'excrement' secreted by the body, and uneasiness about perspiration increasingly demanded that one change clothes on a more regular basis than before. In a culture where people avoided excessive contact with water, clean white linen acted like a sponge that, by removing oily substances from the skin, allowed sweat to be excreted more readily. This was also an education in sensibility in which repugnance toward the oily and dirty diminished tolerance for wearing sweaty garments. Encouraged by the high status that pristine white linen had by then achieved, the power of whiteness to signify cleanliness and status had become irrefutable by the seventeenth century and would only grow in significance throughout the modern era. ${ }^{53}$ Grease was one of the prime targets of early modern whitening strategies.

While these developments were abetted by the hegemony of vision that was emerging during the sixteenth century - which is what many scholars have emphasized - this mounting aversion to grease throws into relief some the problems posed by the very corpulent, whose fat was said to spring from the accumulation of such unctuous fluids. Partly as a result of the Galenic medical model that emphasized the role of the four humours in physical constitutions, throughout the seventeenth century fat people were often lampooned in terms of the sweat and oil that rendered them 'leaky' when compared to the more properly contained bodies that elites aspired to achieve. ${ }^{54}$ To be fat was to be predisposed to an embarrassing overflowing of one's boundaries, and by habitually soiling one's clothes the sweaty fat person risked compromising the imagined purity of whiteness. Yet sartorial whiteness went hand in glove with uprightness and the validation of the firm and solid over the 'loose' and 'soft', qualities that were evident in physical constitutions as in personal character. This reflected an eighteenth-century medical emphasis on fibres rather than fluids. ${ }^{55}$ Concerns about the fluid and the fibrous were combined in the Scottish physician George Cheyne's influential approach to fat, which drew attention to the states, colours, and textures of solids and liquids, all of which were reflected in a person's character. 'A fat, corpulent, and phlegmatic Constitution', he wrote, 'is always attended with loose, flabby, and relaxed Fibres, by their being dissolved and over-soaked in Moisture and Humidity ${ }^{56}$ Wetness and slackness thus seemed to imply one another: looseness of muscle fibres emerged from 
or even caused laxity in other aspects of life, with full-blown corpulence often seen as a logical physical sign of this constitutional lack of firmness. The implications of such slackening included sexual impotence, loss of vigour, and the prospect of seeing the body 'invaded' by fat, ${ }^{57}$ which is more or less what ancient physicians and moralists had already observed.

None of this diminished the importance of visuality in fostering new forms of bodily appearance and experience. There is every reason to concur with Winfried Menninghaus, who sees in the neoclassical art of the eighteenth century the beginnings of a mind-set that still operates today: 'this body subsumed to aesthetic illusion', he writes, 'with its normative youthfulness, its smooth skin free of blemish, its slenderathletic elasticity and nonobscene nudity, anticipates a nowpredominant regulation of the body, its sleekest forms emerging from the world of advertising, cosmetics, and - as analagon of the antique gymnasia so enthusiastically evoked by art historian Johann Winckelmann - the fitness center with its various machines'. ${ }^{58}$ Just as in the art world the fleshy and sensual rococo style was being replaced by a more austere neoclassicism, so too did the dining habits of elites display greater restraint in appetite and less culinary excess. ${ }^{59}$ As Stephen Mennell puts it, these centuries witnessed a break with medieval habits and 'a shift in emphasis from quantitative display to qualitative elaboration' where social status was signalled by more refined repasts and a physique to go with it. ${ }^{60}$ Rather than challenging any of these points, drawing attention to the materiality of fat reveals that the growing containment and closure that many scholars have observed during this period was not only a matter of visuality, but part of a developing kinaesthetic that contributed to the lived experience of containment and closure. A withdrawal from corpulence in bodily frame marched in stride with an accelerating repugnance toward fat and grease as morally problematic substances that one could feel and smell as well as see. Growing intolerance for the various forms of fat reflects a sensory transformation of the white European elite habitus, and underscores the ways in which human senses are often synaesthetically transposed in everyday experience. If fat bodies looked as if they might feel a certain way if touched, then the qualities of greasiness, softness and flabbiness take on considerable importance in understanding the formation of fat stereotypes.

These misgivings about fat did not dispel the fundamentally ambiguous qualities of the substance - after all, the 'foul' kitchen wench could be alluring precisely because of the promise of greasy sexual encounters. The ambiguity of fat was exploited in other 
domains as well. For instance, one of the most provocative developments of this period pertained to the double role that fat played in relation to the perception and experience of decay. Putrefaction was signalled by the presence of foul smells, which the wealthy tried to stave off through the use of powders, perfumes, and other materials. Rather startling is the extent to which highly corruptible fat could be used to conceal the odour of decay and even to preserve or restore youthfulness. Thus elites would frequently make use of pomatums, which consisted of scented animal fat worn on the head and absorbed into the hair and scalp. ${ }^{61}$ The scent of decay could also be washed away with another fat-based product - soap, highquality versions of which began to be imported into England during the late sixteenth century. In time local manufacturers were marketing perfumed soap for personal use as well as for the cleaning of linen and other household items. ${ }^{62}$ Beyond its role in masking odours fat was also a mainstay of cosmetics and skin care. To promote a more youthful appearance one could use pomade, a cream made from animal fat or vegetable oil that promised to clean, lighten and moisturize the hands and face, and for softer hands one could sleep wearing gloves dipped in fat. ${ }^{63}$ Bumgroschen even made a point of reassuring readers that 'there will be plenty [of fat] to spare both for pomatums and the various ointments' that people used in the $1820 \mathrm{~s} .{ }^{64}$

If fats drawn from animal and vegetable sources could be made to perform cleansing and beautifying functions, this could only be accomplished through a quasi-alchemical procedure that transformed the base into the lofty, the filthy into the pure and purifying. Personal fat and grease continued to be seen as potential enemies of health, youth, and decorum. Sweat that accumulated in the armpits, genitals, or buttocks was not only said to 'inflame' those areas, but was liable be reabsorbed by the body, thereby 'disposing the humours to putrefaction', as one author put it. An argument in favour of the localized cleaning that the recent innovation of the bidet could provide, observations like this also spoke to the potential health risks of sweat that was not secreted from the body. ${ }^{65}$ Unsurprisingly, the effluvia of the personal body were cross-referenced with the fluids of urban centres. Like 'so many common sewers to a city', one physician warned, the 'excretory ducts' of the skin were meant 'to carry off redundant humors, which retained, must turn to putrid filth and nastiness'. The same author also explained that warm baths were most effective in opening the pores and releasing this excretion from the body, even though afterwards some might find 'a gross fat substance' floating on the top of the bathwater in such quantities that it is 
'capable of being collected like fat upon broth' ${ }^{66}$ If some proposed that the putrefaction had already begun by eating too many animal products, their views of fat remained quite similar. '[W]e debauch in fat and butter beyond what any stomach can thoroughly digest', pronounced Dr William Grant in the 1770s. Such substances easily became 'rancid' in the body: 'they frequently find their way into the vessels, mix with the blood, are deposited in different parts of our body, and make us fat, and bloated, and big-bellied; then they stagnate and corrupt, breed scurvy, gout, and other diseases' ${ }^{67}$

Thus the physician Malcolm Flemyng was not saying anything particularly new when he described corpulence as resulting from the accumulation of noxious oily fluids - including sweat, urine, and faeces - that had not been properly evacuated from the body. Somewhat more novel was Flemyng's recommendation that fat people should use soap - internally in pill form - because of its properties as a mild diuretic and dissolver of oil. Flemyng's defence of this unorthodox treatment revealed the intimate relationship between cleanliness, health, and morality. Just as soap could restore filthy linen to 'cleanness, sweetness, and whiteness' - the sort of thing elites were already doing to ensure that their clothes were spotless - it could also be eaten to cleanse the fat within, which everyone knew was bereft of such celebrated qualities. ${ }^{68}$ Armed with soap, then, one could fight fat with fat, a practice that would end up being widely recommended through the early nineteenth century. That soap was used to clean middle-class bodies - inside and out-reinforced the subtle but growing alignment of moderately proportioned bodies with cleanliness, morality, and whiteness.

\section{Colonial Grease}

This last term, whiteness, has only received minimal treatment in scholarship on fat, even though intimations of it appear throughout the discourses of grease and corpulence that have been traced so far. It is widely known that the rise of soap as a 'yardstick of civilization' was accompanied by a pronounced distaste for those who fell short of evolving standards of hygiene, whether at home or overseas. Not only was whiteness elevated to a central bourgeois virtue, in terms of racial identity, personal hygiene, and laundry practice, but by the end of the nineteenth century British soap manufacturers were gratuitously using racial imagery to market their products to anxious white consumers. To do this they drew none-too-subtle connections between the filth they wiped from their bodies and the 'great unwashed' both at home and abroad. ${ }^{69}$ The final - and admittedly more speculative - section of 
this essay sketches how perceptions of non-white bodies and customs may have enabled and abetted the growing repugnance toward fat in the West. Whether in the form of grease from meals, sweat from the body, or the excessive accumulation of adipose tissue, research suggests that fat came to represent a source of contamination that levelled attention on the greasy and corpulent bodies of certain nonWestern peoples. The grease Europeans wiped away from their identities rubbed off on their perceptions of others, eventually providing a racial subtext to fat stereotyping that would endure into the twentieth century.

Elsewhere I have argued that the stigmatization of corpulence in the nineteenth century was partly enabled by French and British reports of how certain non-Western cultures, notably those in Africa, China and India, celebrated body fat as sexually and aesthetically desirable. If a prosperous Briton might have been 'congratulated on the portliness of his corporation' in the early nineteenth century ${ }^{70}$ it was largely because it seemed like the just reward for energy and enterprise rather than something deliberately cultivated because it was considered beautiful or desirable. Among the bourgeoisie corpulence signified social status but not physical strength or beauty - this was doubly so for women, who were encouraged to sustain a pleasingly 'moderate' physique (however that was defined) for much of the century. ${ }^{71}$ To become fat despite one's best efforts to the contrary would come to be more excusable than actually wanting to become so. The 'disgusting' desire that certain indigenous people showed for fat was repeatedly contrasted to the purportedly superior tastes and ideals of 'Europeans' and regularly cited in Western weight-loss literature throughout the nineteenth century. ${ }^{72}$ Examining the parallel stigmatization of sweat and grease complements this research by showing how abject desires were also imagined with reference to disturbing substances. ${ }^{73}$ In their study of South Africa John and Jean Comaroff note how in the colonial imagination the loaded term 'grease' conjured up 'the clinging filth of savagery, the grime of uncontained bodies and unsavory associations'. The lascivious connotations of the greasy were widespread, especially among Evangelical Christians who used it to describe a troubling 'stickiness' that marked 'a body that refused to separate itself from the world'. If grease was, in a very real sense, the opposite of 'Grace', ${ }^{74}$ to what extent did grease and corpulence inform one another in European perceptions of the colonial Other?

Here too the early modern era may provide some clues. Consider the case of Egypt, which occupies an interesting place in Western 
perceptions of flesh and fat. It was a land of sensuality and excess for the Romans as well as for Christians, who liked to tell of how the Hebrews abandoned its greasy 'fleshpots' for the more spiritually sustaining fare of manna in the desert. ${ }^{75}$ Some of these images were extended in the early modern era. The Venetian botanist Prospero Alpini commented on how Egyptian women frequently bathe to perform the 'art of fattening' that was also facilitated by ingesting various drugs and injecting themselves with clysters full of bran, sesame oil, and animal fat. Alpini claimed that the flesh that Egyptians deliberately added to their bodies reflected the more prevalent 'vice of the flesh' which 'has invaded the marrow of the people'. Thus Egyptian men are only interested in the 'fleshiest and fattest' of women, and it is because of this twisted desire that 'one finds, down there, many very fat women' ${ }^{76}$ Similar ideas circulated throughout this period. In Shakespeare's Antony and Cleopatra Egypt was the land of luxury and effeminacy where Marc Antony and even Caesar himself 'grew fat' and soft through their sensual escapades. ${ }^{77}$ The idea that men were not quite men in Egypt reflected concerns about the moral and physical effects of life in this region. A late seventeenth-century Dutch report claimed that men in Cairo were so fat that 'they have breasts bigger and thicker than the women'. ${ }^{78}$

Marching in tandem with such observations about corpulent Egyptians was an on-going discussion about the more general fatness of the land, the air, and even the water. Egyptian soil, especially around the Nile River, was repeatedly described as 'fat', so much so that the geographer Pierre d'Avity claimed that 'the inhabitants make it more slender [l'amaigrissent] by mixing some sand into it'. 'The Air of this Country is very hot', complained geographer Patrick Gordon, 'and generally esteemed extremely unwholesome, being always infected with nauseous Vapours, ascending from the fat and slimy Soil of the Earth'. ${ }^{80}$ Variations of this theme were echoed by several other observers. The orientalist Claude-Étienne Savary claimed that the Egyptian air was 'fat, hot, humid' ${ }^{\prime}$ ' while the explorer the Abbé de Binos - drawing upon centuries of lore about the almost magical powers of the Nile - claimed that drinking its water promoted weight gain among Egyptians despite their otherwise modest diet. ${ }^{82}$ Yes, even water could be described as 'fat'. ${ }^{83}$ Others extended ancient remarks about the cognitive 'thickness' of fat people to the land itself, suggesting that enjoying the bounty of the earth could render one soft in the head: 'A fat Soil produceth a fat Understanding' quipped the physician John Arbuthnot. ${ }^{84}$ Despite these environmental causes for why some Egyptians might be predisposed to corpulence, most 
cited cultural factors as being of greater importance. It was the desire for fat that caused so many to become so. Thus the learned men who accompanied Napoleon on campaign in Egypt complained that 'It happens very unfortunately that excessive corpulency is here esteemed a beauty'. ${ }^{85}$

These perceptions of Egypt invoked the rich connotations of fat that have circulated in the West since antiquity. Moreover the latitude with which fat was understood in Egypt was also evident in other regions of the world. In addition to marvelling at the fertile soil of the lands they visited early travellers in Africa commented frequently upon the natives' unexpected use of animal fat, the viscous and malodorous qualities of which seemed to amplify their revulsion at what they saw as the physical ugliness of the people. Accounts of the eating of foulsmelling fatty meat emerged in the seventeenth century, as did stories about how some native peoples smeared their bodies with grease (tales of cannibalism also thrived during this period). ${ }^{86}$ The German explorer Peter Kolb remarked on this practice among the Khoikhoi (widely known as the 'Hottentots'), who smeared their bodies with butter and sheep's fat, mixed with soot, to darken their appearance and protect them from the sun. ${ }^{87}$ Yet if Hottentots were closely linked with fat in the learned imagination, for much of the eighteenth century it was considered a mainly external trait, a sort of cosmetic that was not bound up with their bodies. When explorers did describe physiques they more or less concurred with John Maxwell's 1707 claim that Hottentot stature was 'universally of a middle Size; they are cleanlimb'd, well proportion'd, and very nimble. I never saw a Fat Person among them' ${ }^{88}$

At some point at the end of the eighteenth century explorers began to report on the corpulence of Hottentots as well as other African peoples, with special attention devoted to the deliberate steps they took to fatten themselves beyond what Europeans considered to be acceptable dimensions. ${ }^{89}$ Although the reasons for this 'discovery' of African corpulence are unclear, we know that it took place during roughly the same period that French and British culture began to manifest a more critical attitude towards fat and grease. We also know that in the early nineteenth century the African woman Sara Baartmann was taken from her home to be exhibited in France and Britain as the 'Hottentot Venus' whose body drew as much comment for its corpulence as it did for the sexual and racial fantasies with which it was associated. ${ }^{90}$ References to African corpulence were paralleled by observations made about other non-Western peoples, notably Indians and Chinese, whose elites also shared a penchant for grease as well as 
fat bodies. The links between grease and corpulence could also be framed more explicitly, with both serving as yardsticks of savagery. 'Nations are so much the more brutal and rude', declared an American writer in 1804, 'the more voracious they are, the more disgusting and nauseous things they live on, the more raw and unprepared meats or carrion they devour, and, lastly, the greater avidity they have for pure fat or animal oils'. That overindulgence in fat would produce disgustingly bloated bodies was a logical extension of such a claim. 'All the nations of southern Asia regard obesity as the height of beauty, and in order to acquire it they drink melted butter, or other oleaginous liquors. This taste and conceit the Hindoos have adopted from the Mongolian nations of southern Asia'. ${ }^{91}$ Viewing 'greasiness' as a cognate of corpulence allowed numerous travellers to speak of the occasional encounter with 'a fat, oily Bengalee Babu', ${ }^{92}$ to observe the 'increased oiliness and obesity which always mark the prosperous native', ${ }^{93}$ or to declare Indians generally to be an 'easy, oily people... [who] get fat when they feed well, with the certainty of a pig or a goose' ${ }^{94}$ Such ideas were extended to Africans as well. A 1908 text on human sexuality pointed to 'the well-known fondness of the American negress for anointing her body with cocoanut-oil and bear's grease' as 'a relic of her earlier African barbarism' that had its origins in a desire to make themselves fat for the benefit of their 'dusky admirers'. ${ }^{95}$

\section{Conclusion}

In light of the foregoing discussion we might conclude that Professor Bumgroschen's 1822 proposal came at the crossroads of British and French perceptions of fat. It gestured towards older ideas and practices while pointing to changes that would become more pronounced a century later. While space limitations do not permit a careful tracking of these ideas as they developed over the decades, it is safe to say that by the twentieth century excessive corpulence and greasiness were often positioned as traits that 'civilised' white bodies should not possess, and the two were often conflated in representations of fat people as sweaty, smelly, and immoral. By that time slenderness had become the ultimate display of corporeal 'civilisation' - swollen and misshapen bodies were increasingly described as throwbacks to earlier ways of life or associated with 'savages' overseas and their moral equivalents within the West. ${ }^{96}$ With human fat long gone from the Western pharmacopeia doctors and pharmacists could now look back with wonder at the earlier days of medicine when fat was prized for its vital and healing properties. Even if something marketed as "poor 
sinner's fat' was still being sold in the Netherlands in the early twentieth century, such practices were considered not merely dated but downright primitive, the sort of thing widely associated with the 'cannibals' overseas who were often the same peoples that also admired fat bodies. ${ }^{97}$ By the twentieth century, then, to admire fat in any of its forms could be cited as proof of disgusting 'savage' desires.

Admittedly this essay has adopted a rather expansive approach to the problem of fat, but this has been guided by the belief that charting changes as well as continuities over time provides a perspective that cannot always be obtained by very specialized work. If our contemporary anxieties reflect more recent changes in our society, they may also be viewed as being inflected by a cluster of much older ideas that circulate in the present in subtle ways. Acknowledging the greasy sources of fat stereotyping thus encourages us to conceptualize fat beyond the relatively narrow confines of modernity and visuality. It reminds us that fat is a material substance whose qualities have played a role in informing many of our perceptions of corpulence. The cultural meanings ascribed to these qualities are certainly historical-they change according to the perceptions and requirements of specific periods and places - but these meanings are also sedimented. Seemingly archaic ideas are not so much replaced by newer ones as they are superimposed by them, creating layers of meaning in which the old remains latent in the new and thus available for potential use in a variety of contexts. Our current perceptions of 'fat' are amalgams of the archaic and the recent, making the historical study of this substance a fruitful way of approaching the stuff that stereotypes are made of.

\section{Notes}

1. 'Bumgroschen' is a play on words that evokes the idea of a large or 'grosse' bum as well as a penny (grosch), thus perhaps rendering the exponent of 'save-all-ism' a penny-pinching fat arse.

2. Anonymous (1822), 'Political Economy: Elements of Save-all-ism; or, an Introduction to the noble Science of sifting Cinders. Abridged from the popular Work of Professor Gunthred Bumgroschen', Blackwood's Edinburgh Magazine, 12:70, pp. 525-31, at pp. 527-8.

3. Wilson, Ben (2007), The Making of Victorian Values: Decency and Dissent in Britain, 1789-1837, London: Penguin, pp. 25-6.

4. Huff, Joyce L. (2008), 'Freaklore: The Dissemination, Fragmentation, and Reinvention of the Legend of Daniel Lambert, King of Fat Men', in Marlene Tromp (ed.), Victorian Freaks: The Social Context of Freakery in Britain, Columbus, OH: Ohio State University Press, pp. 37-59; Meegan Kennedy, "Poor Hoo Loo": Sentiment, Stoicism, and the Grotesque in British Imperial Medicine', in Tromp, Victorian Freaks, pp. 79-113. 


\section{Cultural History}

5. For instance, see Wadd, William (1816), Cursory Remarks on Corpulence; or Obesity Considered as a Disease, London: J. Callow.

6. Péhaut, Yves (1999), 'The Invasion of Foreign Foods', in Jean-Louis Flandrin and Massimo Montanari (eds), Food: a Culinary History from Antiquity to the Present, Botsford, et al., (transl.), New York: Columbia University Press, pp. 457-70, at p. 458. The overseas colonies of Ceylon, Malaya, and West Africa were important sources of the palm, cottonseed, and coconut oils needed for the mass production of hard soap. Mohanram, Radhika (2007), Imperial White: Race, Diaspora, and the British Empire, Minneapolis, MN: University of Minnesota Press, pp. 103-4.

7. Littlefield, David with Edward Baker (2004), 'Oil from Whales', in Wilson Heflin, Herman Melville's Whaling Years, Nashville, TN: Vanderbilt University Press, pp. 23140; Otter, Chris (2008), The Victorian Eye: A Political History of Light and Vision in Britain, 1800-1910, Chicago: University of Chicago Press. On the moral implications of gas lighting, see Nead, Lynda (2000), Victorian Babylon: People, Streets and Images in Nineteenth-Century London, New Haven, CT: Yale University Press, pp. 83-101.

8. Although probably not widely available, soap made from human fat was the subject of experiments by the chemist Michel Eugène Chevreul and was regularly cited in discussions of the various kinds of soaps. See Chevreul, Michel Eugène (1823), Recherches chimiques sur les corps gras d'origine animale, Paris: F. G. Levrault, and Pears, Francis (1859), The skin, baths, bathing, and soap, London: published by the author, p. 98.

9. Liebig, Justus (1844), 'Lectures on organic chemistry', The Lancet, 1:13, pp. 361-4, at p. 362. This strange story was repeated throughout the nineteenth century.

10. Quoted in Prothero, Stephen (2001), Purified by Fire: A History of Cremation in America, Berkeley: University of California Press, p. 131.

11. Lodium, L. (1908), 'Some Curios in Candledom', The Illuminating Engineer, 3:10, pp. $535-8$.

12. Stearns, Peter N. (1997), Fat History: Bodies and Beauty in the Modern West, New York: NYU Press; Gilman, Sander (2004), Fat Boys: A Thin Book, Lincoln, NE: University of Nebraska Press; Vigarello, Georges (2010), Les métamorphoses du gras: histoire de l'obésité, Paris: Seuil; Farrell, Amy Erdman (2011), Fat Shame: Stigma and the Fat Body in American Culture, New York: NYU Press.

13. Levy-Navarro, Elena (2008), The Culture of Obesity in Early and Late Modernity, Basingstoke: Palgrave, p. 37.

14. The literature on disgust has expanded considerably in recent years. See, for instance, Miller, William Ian (1997), The Anatomy of Disgust, Cambridge, MA: Harvard University Press; Nussbaum, Martha (2004), Hiding from Humanity: Disgust, Shame, and the Law, Princeton: Princeton University Press; and Korsmeyer, Carolyn (2011), Savoring Disgust: The Foul and the Fair in Aesthetics, Oxford: Oxford University Press. On fat and 'abjection' see Braziel, Jana Evans (2001), 'Sex and Fat Chics: Deterritorializing the Fat Female Body', in Jana Evans Braziel and Kathleen LeBesco (eds), Bodies out of Bounds: Fatness and Transgression, Berkeley: University of California Press, pp. 231-54.

15. Boivin, Nicole (2008), Material Cultures, Material Minds: The Impact of Things on Human Thought, Society, and Evolution, Cambridge: Cambridge University Press, p. 47.

16. Boivin, Nicole (2004), 'Mind over Matter? Collapsing the Mind-Matter Dichotomy in Material Culture Studies', in Elizabeth DeMarrais, Chris Gosden, and Colin 


\section{The Sources of Modern Perceptions of Fat}

Renfrew (eds), Rethinking Materiality: The Engagement of Mind with the Material World, Cambridge: McDonald Institute for Archaeological Research, pp. 63-71, at p. 64.

17. Keane, Webb (2005), 'Signs are Not the Garb of Meaning: On the Social Analysis of Material Things', in Daniel Miller (ed.), Materiality, Durham, NC: Duke University Press, pp. 182-205, at p. 194.

18. Onians, R. B. (1951), The Origins of European Thought about the Body, the Mind, the Soul, the World, Time, and Fate, Cambridge: Cambridge University Press, p. 213.

19. Aristotle (1991), Problems, E. S. Forster (transl.), Book III, 871b32-1341, in Complete Works, Jonathan Barnes (ed.), Princeton: Princeton University Press, p. 29.

20. Lee, Mireille M. (2009), 'Body-Modification in Classical Greece', in Thorsten Fögen and Mireille M. Lee (eds), Bodies and Boundaries in Graeco-Roman Antiquity, New York: De Gruyter, pp. 155-180, at p. 157; Pliny (1963), Natural History, vol. VIII, W. H. S. Jones (transl.), Cambridge, MA: Harvard University Press, pp. 36-9. Pliny (1963), Natural History, Volume VIII, W. H. S. Jones (transl.), Cambridge, MA: Harvard University Press, Book xxvIII. XIII, pp. 36-9. Even the layer of greasy 'filth' that collected on the walls of baths and gymnasia - as well as on the surface of statues - had medicinal value. Dioscorides (2005), De materia medica, Lily Y. Beck (transl.), Hildesheim, Germany: Georg Olms Verlag, pp. 25-33, 116-21.

21. As Virgil noted, 'never does it crumble when worked in the hands, but like pitch grows sticky in the fingers when held'. Virgil (1978), Georgics, in Virgil, I, H. Rushton Fairclough (transl.), Cambridge, MA: Harvard University Press, 2.248-250, pp. 1323. See also Columella (1941), On Agriculture I, Harrison Boyd (transl.), Cambridge, MA: Harvard University Press, Bоok II, I. 6-II, p. 109.

22. Meneley, Anne (2008), 'Oleo-Signs and Quali-Signs: The Qualities of Olive Oil', Ethnos, 73:3, pp. 303-26, at p. 312.

23. Horace reported 'the great feelings of fastidium [that are stirred up] in the stomach, if the slaveboy has pawed the winecup with greasy hands while stealing a sip'. Quoted in Kaster, Robert (2005), Emotion, Restraint, and Community in Ancient Rome, Oxford: Oxford University Press, p. 108. This was also evident in Marcus Aurelius' reaction to the thought of immersing himself in the less-than-pristine waters of a public bath: 'What is bathing when you think about it - oil, sweat, greasy water, everything loathsome'. Quoted in Fagan, Garrett G. (1999), Bathing in Public in the Roman World, Ann Arbor, MI: University of Michigan Press, p. 188.

24. Pliny (1951), The Natural History, Volume V, H. Rackham (transl.), Cambridge, MA: Harvard University Press, Book VII, XXXVII, p. 153. Here Pliny echoed what physicians had been saying for centuries: from the Hippocratic authors to Celsus, Galen, and Soranus, all agreed that excess body fat was unhealthy, unseemly, and a cause of sterility and barrenness. Hippocrates (1931), Regimen, in Hippocrates, W. H. S. Jones (transl.), Cambridge, MA: Harvard University Press, vol. 4, pp. 353-65; Celsus (1935), De Medicina, W. G. Spencer (transl.), Cambridge, MA: Harvard University Press, Book II, p. 97; Galen (1951), Hygiene, Henry E. Sigerist (transl.), Springfield, IL: Charles C. Thomas, p. 20; Soranus (1991), Soranus' Gynecology, Owsei Temkin (transl.), Baltimore: Johns Hopkins University Press, pp. 19, 29.

25. Plato (1980), The Laws, Thomas L. Pangle (transl.), New York: Basic Books, 806d807b, pp. 196-7; Plutarch (1914), Lives, I, Bernadotte Perrin (transl.), Cambridge, MA: Harvard University Press, X, p. 233; Gowers, Emily (1996), The Loaded Table: Representations of Food in Roman Literature, Oxford: Clarendon Press, pp. 147-8.

26. Corbeill, Anthony (1996), Controlling Laughter: Political Humor in the Late Roman Republic, Princeton: Princeton University Press, pp. 139-43; Phang, Sara Elise 


\section{Cultural History}

(2008), Roman Military Service: Ideologies of Discipline in the Late Republic and Early Principate, Cambridge: Cambridge University Press, pp. 264-6.

27. Hill, Susan E. (2011), Eating to Excess: The Meaning of Gluttony and the Fat Body in the Ancient World, Santa Barbara, CA: Praeger, p. 13.

28. Vesalius, Andreas [1543] (1998), On the Fabric of the Human Body, Book I: The Bones and Cartilages, William Frank Richardson (transl.), San Francisco: Norman Publishing, p. 374.

29. Taussig, Michael (1987), Shamanism, Colonialism, and the Wild Man: A Study in Terror and Healing, Chicago: University of Chicago Press, pp. 237-8; van Haestens, Hendrik (1615), La nouvelle Troye, ou Memorable histoire du siege d'Ostende, Leiden: chez Loys Elzevier, p. 147: '[L]es Chirurgiens de la ville y allerent apres \& en rapporterent des sacs plein de graisse d'hommes, qu'ils avoient tirez des corps'.

30. Brocard, Michèle (2007), Lumières sur la sorcellerie et le satanisme, Divonne-les-Bains: Cabédita, p. 29.

31. Stuart, Kathy (1999), Defiled Trades and Social Outcasts: Honor and Ritual Pollution in Early Modern Germany, Cambridge: Cambridge University Press, pp. 157-8; Ferrari, Giovanna (1987), 'Public Anatomy Lessons and the Carnival: The Anatomy Theatre of Bologna', Past $\mathcal{E}$ Present, 117, pp. 50-106, at p. 101; Cotugno, Domenico (1775), A treatise on the nervous sciatica, or, nervous hip gout, London: J. Wilkie, pp. 127-8.

32. Hill, John (1751), A history of the materia medica, London: T. Longman, C. Hitch and L. Hawes, pp. 875-6.

33. Cabanès, Augustin (1905), Remèdes d'autrefois: comment se soignaient nos pères, Paris: Maloine, pp. 51-2.

34. Thomas, Keith (1971), Religion and the Decline of Magic, New York: Oxford University Press, pp. 189-91. Thus one Munich executioner accused of practicing white magic defended himself by showing that he only used 'natural means' that included 'herbs, roots, and human fat'. Stuart, Defiled Trades, p. 161.

35. Jain, Ratesh K. and Dai Fukumura (2009), 'Angiogenesis in Development, Disease, and Regeneration', in Matteo Santin (eds), Strategies in Regenerative Medicine, New York: Springer, pp. 189-228, at p. 204.

36. Stuart, Defiled Trades, p. 160.

37. Elworthy, Frederick Thomas (1900), Horns of honour and other studies in the by-ways of archaeology, London: John Murray, p. 187. Such practices were reported to have been alive and well in Russia and Eastern Europe towards the end of the nineteenth century, where some thieves were brought up on similar grisly charges. Strack, Hermann L. (1909), The Jew and Human Sacrifice [Human Blood and Jewish Ritual], Henry Blanchamp (transl.), London: Cope and Fenwick, pp. 105-8, 115-7.

38. Camporesi, Piero (1990), The Fear of Hell: Images of Damnation and Salvation in Early Modern Europe, Lucinda Byatt (transl.), Cambridge: Polity, p. 129; Vukanović, T. P. (1989), 'Witchcraft in the Central Balkans I: Characteristics of Witches', Folklore, 100:1, pp. 9-24, at p. 12; Otten, Charlotte F. (1986), A Lycanthropy Reader: Werewolves in Western Culture, Syracuse: Syracuse University Press, p. 27.

39. Avramescu, Cătǎlin (2009), An Intellectual History of Cannibalism, Alistair Ian Blythe (transl.), Princeton: Princeton University Press, p. 255.

40. Abry, Christian and Alice Joisten (2002), 'Trois notes sur les fondements du complexe de Primarette: loups garous, cauchemars, prédations et graisses', Le Monde alpin et rhodanien, 30:1-2, pp. 135-61.

41. Crétineau-Joly, J. (1843), Histoire de la Vendée militaire, 2nd ed.: Paris: Librairie de Charles Gosselin, vol. II, p. 67. 


\section{The Sources of Modern Perceptions of Fat}

42. Hill, History of the materia medica, p. 876.

43. Parent-Duchâtelet, A.-J.-B. (1836), Hygiène publique, ou Mémoires sur les questions les plus importantes de l'hygiène, Paris: Baillière, vol. 2, pp. 22-4.

44. See Chevreul, Recherches chimiques; Huff, Joyce L. (2005), 'Corporeal Economies: Work and Waste in Nineteenth-Century Constructions of Alimentation', in Christopher E. Forth and Ana Carden-Coyne (eds), Cultures of the Abdomen: Diet, Digestion and Fat in the Modern World, New York: Palgrave, pp. 31-49.

45. Connor, Steve (2004), The Book of Skin, Ithaca, NY: Cornell University Press, p. 203.

46. In the collection of stories known as the Heptameron, Marguerite de Navarre invoked biblical references to the insensateness of adipose to criticize carnal individuals (les charnelz) who are 'too encased in their fat [graisse]' to know whether or not they even have a soul. de Navarre, Marguerite (1560), L'Heptameron, Paris: Benoit Prevost, p. 382.

47. Oudin, Antoine (1656), Curiositez françoises, pour supplément aux dictionnaires, Rouen: Antoine de Sommaville, pp. 198-9.

48. McNeill, Fiona (2007), Poor Women in Shakespeare, Cambridge: Cambridge University Press, p. 45.

49. Shakespeare, William (1966), A Comedy of Errors, in W. J. Craig (ed.), Complete Works, London: Oxford University Press, p. 108.

50. Cotgrave, Randle (1611), in A Dictionarie of the French and English Tongues, London: Adam Islip, unpaginated. See also Williams, Gordon (1994), A Dictionary of Sexual Language and Imagery in Shakespearean and Stuart Literature, London: Athlone, p. 972.

51. Toulalan, Sarah (2011), “Unripe” bodies: children, sex and the body in early modern England', in Sarah Toulalan and K. Fisher (eds), Bodies, sex and desire from the Renaissance to the Present, Basingstoke, UK: Palgrave.

52. Erasmus, Desiderius [1530] (1985), On Good Manners for Boys, in J. K. Sowards (ed.), Collected Works of Erasmus, Toronto: University of Toronto Press, vol. 25, pp. 269-89, at p. 283.

53. Vigarello, Georges (1988), Concepts of Cleanliness: Changing Attitudes in France since the Middle Ages, Jean Birrell (transl.), Cambridge: Cambridge University Press, pp. 60, 73.

54. Baker, Naomi (2010), Plain Ugly: The Unattractive Body in Early Modern Culture, Manchester: Manchester University Press, pp. 120-1.

55. Vigarello, Les métamorphoses, pp. 113-6.

56. Cheyne, George (1724), An essay of health and long life, London: George Strahan, p. 188.

57. Flemyng, Malcolm (1760), A discourse on the nature, causes, and cure of corpulency, London: L. Davis and C. Reymers, p. 12.

58. Menninghaus, Winfried (2003), Disgust: The Theory and History of a Strong Sensation, Howard Eiland and Joel Golb (transl.), Albany, NY: SUNY Press, p. 92.

59. Camporesi, Piero (1998), Exotic Brew: The Art of Living in the Age of Enlightenment, Christopher Woodall (transl.), Cambridge: Polity, pp. 99-100.

60. Mennell, Stephen (1996), All Manners of Food: Eating and Taste in England and France from the Middle Ages to the Present, $2^{\text {nd }}$ ed.: Champaign, IL: Illini Books, p. 33.

61. Brown, Kathleen M. (2009), Foul Bodies: Cleanliness in Early America, New Haven. CT: Yale University Press, p. 33.

62. Smith, Virginia (2007), Clean: A History of Personal Hygiene and Purity, Oxford: Oxford University Press, pp. 192-3. 


\section{Cultural History}

63. Martin, Morag (2009), Selling Beauty: Cosmetics, Commerce, and French Society, 17501830, Baltimore: Johns Hopkins University Press, p. 16.

64. Anonymous, 'Political Economy', p. 528.

65. Vigarello, Concepts of Cleanliness, p. 107.

66. Lucas, C. (1756), An essay on waters, London: A. Millar, pp. 211, 216.

67. Grant, William (1779), Observations on the nature and cure of fevers, $3^{\text {rd }}$ ed.: London: T. Cadell, vol. 1, p. 264.

68. Flemyng, Discourse on corpulency, pp. 8, 20-2.

69. Brown, Foul Bodies, p. 266; McClintock, Anne (1995), Imperial Leather: Race, Gender and Sexuality in the Colonial Contest, London: Routledge, pp. 207-31.

70. Wadd, William (1824), 'The Physician. - No. XII. On corpulence', New monthly magazine, 10, pp. 181-6, at p. 181.

71. Brillat-Savarin, Jean Anthelme [1825] (1845), Physiologie du goût, ou méditations de gastronomie transcendante, Paris: Charpentier, p. 220.

72. Forth, Christopher E. (2012), 'Fat, Desire, and Disgust in the Colonial Imagination', History Workshop Journal, 73, in press.

73. See Anne McClintock's discussion of the role played by images of dirt and cleanliness in colonial encounters. McClintock, Imperial Leather, pp. 71-3.

74. Comaroff, John L. and Jean Comaroff (1997), Of Revelation and Revolution: The Dialectics of Modernity on a South African Frontier, Chicago: University of Chicago Press, vol. 2, pp. 189, 225, 336.

75. Drawing upon biblical imagery from Exodus and Numbers, the author of L'Homme charnel, et spiritual promoted a Christian life of hunger and thirst in which 'we leave forever the fat [la graisse] and fleshpots [les oignons] of Egypt' in order to feast on the spiritual fare of manna in the desert. Anonymous (1667), L'Homme charnel, et spiritual, Cologne: Baltazar d'Egmondt, p. 18. Philo of Alexandria explicitly cast Egypt as the 'land of the body' where passions and sensuality reigned over spirit the migration of the 'Chosen People' from this corporeal landscape was thus a symbol of their triumph over the flesh. Pearce, Sarah J. K. (2007), The Land of the Body: Studies in Philo's Representation of Egypt, Tübingen: Mohr Siebeck.

76. Alpini, Prospero (1591), De medicina Aegyptiorum, Venice: Francesco de Franceschi, Book III, Ch. 15; Alpini, Prospero [1591] (1980), La Médecine des Egyptiens (15811584), R. de Fenoy (transl.), Cairo: Institut français d'archéologie orientale, pp. 294-304, at pp. 294-5.

77. Fernie, Ewan, et al. (eds) (2005), Reconceiving the Renaissance: A Critical Reader, Oxford: Oxford University Press, p. 299.

78. Dapper, Olfert (1686), Description de l'Afrique, Amsterdam: Wolfgang, Waesberge, Boom \& van Someren, p. 94.

79. d'Avity, Pierre (1637), Description générale de l'Afrique, Paris: Claude Sonnius, p. 264.

80. Gordon, Patrick (1732), Geography Anatomiz'd: or the Geographical Grammar, London: J. and P. Knapton, p. 303.

81. Savary, Claude Etienne (1786), Lettres sur l'Egypte, Paris: Onfroi, Libraire, vol. 3, p. 8.

82. de Binos, Abbé Maria Dominicus (1787), Voyage par l'Italie, en Egypte au Mont-Liban et en Palestine, ou Terre Sainte, Paris: Boudet, vol. 1, p. 290; Burleigh, Nina (2007), Mirage: Napoleon's Scientists and the Unveiling of Egypt, New York: HarperCollins, p. 105.

83. The 'fatness' of soil could be imparted to bodies of water, such as those whose sources were rain and melted snow. Observing that soft water contained 'fat and oily Particles', the German geographer Bernhard Varen claimed in 1650 that the Seine was a river blessed with 'fat and soft Waters' that rendered the land fertile as 


\section{The Sources of Modern Perceptions of Fat}

well. Varenius, Bernhard (1734), A compleat system of general geography, Mr Dugdale (transl.), 2nd ed.: London, Stephen Austen, pp. 328, 344.

84. Arbuthnot, John (1733), An essay concerning the effects of air on human bodies, London: J. Tonson, p. 124.

85. Carrie, Citizen (1800), 'On the Topography of Manouf, in the Delta', in Memoirs relative to Egypt, written in that country during the campaigns of General Bonaparte, London: R. Phillips, p. 133.

86. Smith, A. S. (1991), 'Living off the Fat of the Land: Resource Exploitation at Kasteelberg, Southwestern Cape, South Africa', Nyame akuma, 36, pp. 20-3; Burke, Timothy (1996), Lifebuoy Men and Lux Women: Commodification, Consumption, and Cleanliness in Modern Zimbabwe, Durham, NC: Duke University Press, pp. 23-34. If French missionaries in North America commented approvingly on the athletic physiques of native males - sometimes with favorable comparisons to classical models - they denigrated the shamans who smeared their bodies with pitch by invoking the interlinked imagery of grease, filth, sexuality, and femininity. Ouellet, Réal (1989), 'Sauvages d'Amérique et discours hétérologique', Études littéraires, 22:2, pp. 109-22, at pp. 115-6.

87. Kolb, Peter (1731), The present state of the Cape of Good-Hope, G. Medley (transl.), London: W. Innys, pp. 49-50, 52.

88. Maxwell, John (1707), 'An account of the Cape of Good Hope', Philosophical transactions, 310, pp. 2423-33, at pp. 2424-5.

89. de Chénier, Louis (1788), Recherches historiques sur les Maures, et histoire de l'Empire de Maroc, Paris, chez l'auteur, vol. 3, p. 127; Park, Mungo (1800), Travels to the Interior Districts of Africa, London, James Humphreys, p. 181; Barrow, John (1801), An Account of Travels into the Interior of Southern Africa in the Years 1797 and 1798, London, A. Strahan, p. 281; Durand, Jean-Baptiste-Léonard (1807), Voyage au Sénégal fait dans les années 1785 et 1786, Paris, Dentu, p. 89.

90. See, for instance, Gilman, Sander (1985), 'Black Bodies, White Bodies: Toward an Iconography of Female Sexuality in Late Nineteenth-Century Art, Medicine, and Literature', Critical Inquiry, 12, pp. 204-42; and Fausto-Sterling, Anne (1995), 'Gender, Race, and Nation: The Comparative Anatomy of "Hottentot" Women in Europe, 1815-1817', in Jacqueline Urla and Jennifer Terry (eds), Deviant Bodies: Critical Perspectives on Difference in Science and Popular Culture, Bloomington, IN, Indiana University Press, pp. 19-48.

91. Anonymous (1804), 'On the Propensity of Several Nations to Greasy Meats and Drinks', The Literary Magazine, and American Register, 2:7, p. 47.

92. Bacon, Gertrude (1899), 'Two Indian Days', The Ludgate, 8, pp. 436-44, at p. 437.

93. Craik, Henry (1908), Impressions of India, London: Macmillan and Co., p. 233.

94. Blanchard, Sidney Laman (1867), Yesterday and To-day in India, London: Wm. H. Allen \& Co., p. 89.

95. Parke, J. Richardson (1906), Human Sexuality: A Medico-Literary Treatise on the Laws, Anomalies, and Relations of Sex, Philadelphia: Professional Publishing Co., p. 74.

96. Forth, 'Fat, Desire, and Disgust'; Farrell, Fat Shame; Carden-Coyne, Ana (2009), Reconstructing the Body: Classicism, Modernism, and the First World War, Oxford: Oxford University Press, p. 249.

97. Von Andel, M. A. (1922), 'Adeps Hominis: A Relic of Prehistoric Therapy', American Journal of Pharmacy, 94, pp. 665-71; Thompson, C. J. S. (1893), 'Some Curiosities of Ancient Materia Medica', The Western Druggist, 15:4, pp. 144-7; Anonymous (1904), 'From the Editor's Notebook', The Medical Standard, 27:2, pp. 89-90. 